
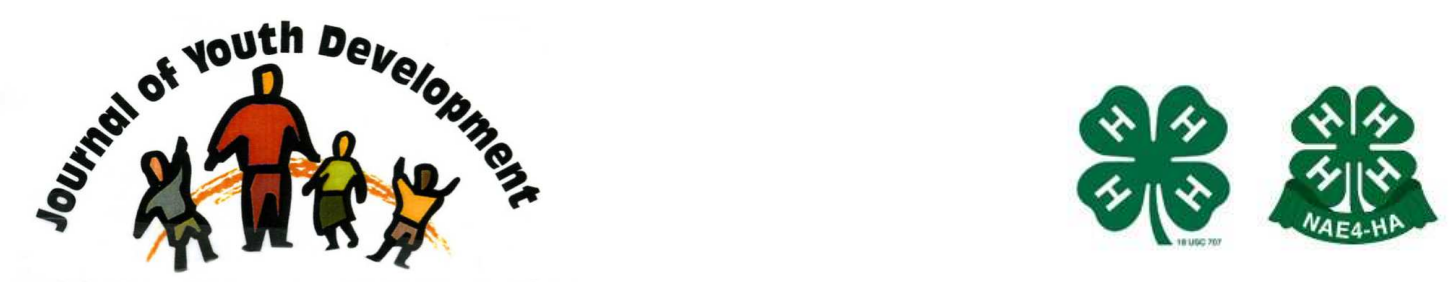

Bridging Research \& Practice

\title{
An Agricultural Apprenticeship Program for Youth in Trinidad, West Indies: \\ Can it Meet the Caribbean's Urgent Need for Younger Farmers?
}

\author{
Wayne G. Ganpat \\ Ministry of Agriculture, Land and Marine Resources \\ Trinidad and Tobago, W.I. \\ waygan@flowtrinidad.net
}

Nicole Webster

Department of Agricultural Extension

Pennsylvania State University 


\title{
JOURNAL OF YOUTH DEVELOPMENT \\ bridging research and practice

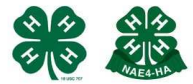

Volume 5, Number 2, Summer 2010

Article 100501FA004

\section{An Agricultural Apprenticeship Program for Youth in Trinidad, West Indies: \\ Can it Meet the Caribbean's Urgent Need for Younger Farmers?}

\author{
Wayne G. Ganpat \\ Ministry of Agriculture, Land and Marine Resources \\ Nicole Webster \\ Pennsylvania State University
}

\begin{abstract}
To address the aging farmer population in Trinidad, W.I., a situation common to the Caribbean region, a Youth Apprenticeship Program in Agriculture (YAPA) was initiated. An assessment of its effectiveness was conducted in 2007. Results indicated that present trainees went into agriculture to make "additional" income and for self employment, with "contributing to national food security" being ranked lower. They were generally satisfied with the extent of field work, the experience gained and trainers' knowledge and skills. However, they would leave agriculture if they received other employment opportunities or if they were not provided with key resources such as land and soft loans. Past YAPA trainees had significantly changed $(p<.05$ level) attitudes regarding farming; being less optimistic than present trainees about the future of farming. Recommendations included greater involvement of young persons in the restructuring of the program and overall curriculum redesign to make it more technology oriented.
\end{abstract}

\section{Introduction}

Youth's lack of motivation and willingness to engage in agricultural activities - a debilitating factor for a slow growth in the agricultural industry is a prevalent issue within both, the developed and developing countries (James, 2005; Odhiambo, 2001; Russell, 1993; The World Bank, 2001, 2006a, 2006b). This lack of motivation and unwillingness is largely due to the negative stigma associated with those involved in agricultural activities (Divyakirti, 2002). Youth across the globe have connected agricultural involvement to being part of the working class of manual laborers who earn modest means and rarely contribute to the overall well being 
of society. It is these stigmas and perceptions that have disengaged the youth in the agriculture industry (FAO, 2001; Rivera, 2001; The World Bank, 2001). One country that has begun to address these issues through a youth development approach is Trinidad and Tobago. The Trinidad government reasoned that a participatory programme was needed to attract and sustain youths in agricultural pursuits - and therefore organized an initiative in an attempt to enhance food security, create viable employment options for young people in the agricultural sector and reduce the average age of its farm population.

This initiative is important because most other countries in the Caribbean are facing a similar problem of an aging farmer population and youth disinterest in agriculture. Moreover, unlike Trinidad and Tobago which has an energy based economy, the economies of most other countries in the region are agriculture based.

The Youth Apprenticeship Programme in Agriculture (YAPA) was started in 2003 with the primary goal of encouraging youths between the ages of 17 and 25 years to participate in agricultural activities in the country. Such agricultural activities would include the technical, professional, and business domains. Through their participation, it was hoped, that young people would come to realize the importance of agriculture in creating a self-sufficient and sustainable nation and in providing career and employment opportunities. More importantly, youth, in recognizing their potential, would forge new attitudes, engage the industry and ultimately realize a productive way of life.

The YAPA model consists of two phases. Phase one, a six to eight week programme conducted in cycles each year was designed to place young people as interns on a range of successful private and public sector agricultural farm enterprises. The purpose of this was to expose them to developing practical skills in farm management, livestock and crop production, and in organizational operations and processes. After the completion of Phase one, students apply for Phase two. This phase is conducted over a nine month period and participants are involved in crop and livestock production, food processing, aquaculture and apiculture. Computer literacy as well as training to improve the life skills of these young people is also taught. Members of staff of the Ministry of Agriculture (2004) are assigned to the role of coordinators to facilitate the teaching and practical aspects of the programme. It is expected that at the end of this phase, these young persons would be able to engage in productive farming or in an agribusiness enterprise.

Despite the general feeling and public pronouncements that the YAPA is a successful programme, development workers have several questions related to its effectiveness and replicability. Was it genuinely meeting the needs of youth across the country who were interested in agriculture and more importantly, was this a model that could be used in other Caribbean countries that were facing similar issues? The general objective of the study therefore was to assess whether the YAPA programme was meeting the needs of youth trainees, and more importantly to examine it as a model for youth engagement in agriculture across the Caribbean region.

\section{Methods}

The study was conducted during the course of a two day meeting of trainees in the Northern and Southern parts of the country in 2007. A survey instrument was administered to all youth trainees present. Fifty-seven (57) trainees out of a total enrollment sixty-six (66) were surveyed, representing a response rate of $86 \%$. The self-reporting instrument sought to capture 
some personal information, reasons for entering the program, trainees' perceptions of some elements of the programs as well as satisfaction with key areas and their present attitudes toward farming. Reasons for possibly leaving the agriculture fields were also explored.

Perceptions, satisfaction levels and reasons were measured using five point rating scales, with highest scores (5) indicating very good perceptions, very satisfied, and most influential reasons for entering agriculture and lowest scores (1) reflecting the opposite. The attitude scale consisted of positive and negative worded statements. Trainees were asked to respond to the sentiments expressed in each statement with either strongly agree (SA), agree (A), undecided $(U)$, disagree (D) or strongly disagree (SD). The response to each attitude statement was scored $1(\mathrm{SD})$ to 5 (SA) for positively worded statements and scoring reversed for negatively worded statements. Higher mean scores indicate positive predisposition and lower mean scores reflect negative predisposition toward the sentiment expressed in the attitude statement. Mean scores above 2.5 reflect a tendency to a positive disposition and means 2.5 and below reflect negative dispositions. The reliability of the scale was estimated at 0.65 (Cronbach alpha).

A second follow up survey was done among past YAPA trainees who had been out of the system for at least six months and who would have had time to face the "real word" of agriculture with all its uncertainties. Based on information provided, some 37 past trainees were contacted and interviewed. This survey sought to capture the present attitudes of these trainees and to compare these attitudes with those presently in the program. The same instrument was used. All results were analyzed using SPSS 11.0 and presented as descriptive statistics.

\section{Results}

\section{Participation}

Since the inception of the YAPA programme in 2003, some 5042 persons have graduated from Phase 1 of the program. There was an even distribution of gender throughout the years, nearly $56 \%$ males (2718) and $44 \%$ females (2324). During Phase 2, there was a reduction in the total number of participants. During this phase, only 221 individuals graduated and the majority of the participants were males (116). Year 1 of Phase 2 had the lowest enrollment of females (4), but by the end of year 2006, there were 66 females who had graduated from the programme. Lower numbers of participants in Phase 2 was mainly due to the Agriculture Ministry's human resource and accommodation capacity to facilitate a nine month training course.

\section{Characteristics of Sample Surveyed}

The sample of YAPA participants in Table 1 reflects that the trainees consisted of $53 \%$ females and $47 \%$ males, with $60 \%$ coming from the Northern part of the country and $40 \%$ from southern regions. Seventy percent (70\%) indicated that they had previous farming experience, $65 \%$ indicated that they studied Agricultural Science in school and 56\% were from a farm family. The minority (37\%) indicated that they had passed the subjects required for them to get a full certificate from the Caribbean Examinations Council (CXC), the recognized certification body for the region. 
Table 1

Characteristics of Trainees Surveyed

\begin{tabular}{|l|l|l|}
\hline Characteristics & $\begin{array}{l}\text { Present YAPA } \\
(\mathbf{n = 5 7 )} \\
(\%)\end{array}$ & $\begin{array}{l}\text { Post YAPA } \\
(\mathbf{n = 3 7 )} \\
(\%)\end{array}$ \\
\hline $\begin{array}{l}\text { Region } \\
\text { North } \\
\text { South }\end{array}$ & $34(59.6)$ & $17(45.9)$ \\
\hline $\begin{array}{l}\text { Gender } \\
\text { Male } \\
\text { Female }\end{array}$ & $23(40.4)$ & $20(54.1)$ \\
\hline $\begin{array}{l}\text { From Farm Family? } \\
\text { Yes } \\
\text { No }\end{array}$ & $27(47.4)$ & $16(43.2)$ \\
\hline $\begin{array}{l}\text { Previous Farm Exp? } \\
\text { Yes } \\
\text { No }\end{array}$ & $30(52.6)$ & $21(56.8)$ \\
\hline $\begin{array}{l}\text { Did Agri. Science? } \\
\text { Yes } \\
\text { No }\end{array}$ & $25(46.1)$ & $25(67.6)$ \\
\hline $\begin{array}{l}\text { Full CXC Certificate } \\
\text { Yes } \\
\text { No }\end{array}$ & $17(70 \%)$ & $12(32.4)$ \\
\hline
\end{tabular}

The characteristics of the sample of post YAPA trainees in Table 1 was similar to the sample of present trainees on the basis of gender, whether they came from a farm family, and previous farming experience. However, a slight majority was from the Southern region, and indicated that they had full CXC certificates. Compared to the present trainees a smaller amount of post YAPA trainees responded (16\%) that they "did Agricultural Science in school."

Table 2 provides details on the ranking of reasons to enter agriculture, satisfaction levels with several program areas, trainees' perception of trainers and reasons not to pursue agriculture.

\section{Reasons to enter agriculture}

Reasons ranked highest were "to generate additional income," an "opportunity for self employment," belief that "farming is interesting/fascinating" and "love of working with nature." While "to improve the nation's food security" and to make farming the "main means of living" were rated as important, other reasons such as "the influence of friends," and "the influence of family" rated high with participants. "The need for the stipend," trainees' unemployment status, and having studied Agricultural Science at school were the lowest ranked reasons, having the highest percentages of little or no influence on trainees' decision to enter the programme.

\section{Satisfaction with program elements}

Overall, trainees were very satisfied with the amount of fieldwork, the experienced gained from the program, and the informal discussions about farming in the field. While the majority of trainees were also satisfied with the tools and equipment provided, and the knowledge and skills of the trainers, there was some dissatisfaction and these attracted lower mean scores. 
There were greater levels of dissatisfaction with "the opportunities afforded to them to visit farms," "the respect provided to them by the trainers" and "the agricultural projects involved with." Highest levels of dissatisfaction were with the co-operation of other trainees and the amount of classroom work. Trainees expressed most dissatisfaction with the facilities for "changing, washing, and lavatory, etc."

\section{Table 2}

Ranking of reasons to enter agriculture, satisfaction levels of program areas, perception of trainers and reasons not to pursue agriculture based on mean scores $(\mathrm{N}=57)$

\begin{tabular}{|c|c|c|c|}
\hline $\begin{array}{l}\text { Reasons to enter } \\
\text { Agriculture }\end{array}$ & $\begin{array}{l}\text { Satisfaction Level } \\
\text { with selected } \\
\text { program areas }\end{array}$ & $\begin{array}{l}\text { Perception of } \\
\text { trainers }\end{array}$ & $\begin{array}{l}\text { Reasons not to } \\
\text { pursue agriculture in } \\
\text { future }\end{array}$ \\
\hline $\begin{array}{l}\text { 1. To be able to generate } \\
\text { additional income in the } \\
\text { future }\end{array}$ & $\begin{array}{l}\text { 1. The amount of field } \\
\text { work done }\end{array}$ & $\begin{array}{l}\text { 1. Their technical } \\
\text { knowledge of } \\
\text { agriculture }\end{array}$ & $\begin{array}{l}\text { 1. Get some other job } \\
\text { offer }\end{array}$ \\
\hline $\begin{array}{l}\text { 2. Saw an opportunity for } \\
\text { self employment }\end{array}$ & $\begin{array}{l}\text { 2.The overall experience } \\
\text { gained }\end{array}$ & $\begin{array}{l}\text { 2. Their practical } \\
\text { farming skills }\end{array}$ & $\begin{array}{l}\text { 2. Insufficient technical } \\
\text { support from the } \\
\text { Ministry }\end{array}$ \\
\hline $\begin{array}{l}\text { 3. Believe farming is } \\
\text { fascinating/interesting }\end{array}$ & $\begin{array}{l}\text { 3.The informal } \\
\text { discussions in the field } \\
\text { about farming }\end{array}$ & $\begin{array}{l}\text { 3. In motivating young } \\
\text { persons to be the best } \\
\text { they can be }\end{array}$ & $\begin{array}{l}\text { 3. Do not get further } \\
\text { assistance from } \\
\text { agencies e.g. Loans }\end{array}$ \\
\hline $\begin{array}{l}\text { 4. Love working with } \\
\text { nature }\end{array}$ & $\begin{array}{l}\text { 4. The tools and } \\
\text { clothing provided for } \\
\text { field work }\end{array}$ & $\begin{array}{l}\text { 4. Their interest in } \\
\text { helping me become a } \\
\text { true farmer }\end{array}$ & $\begin{array}{l}\text { 4. Do not get land I } \\
\text { heard was promised }\end{array}$ \\
\hline $\begin{array}{l}\text { 5. To improve the nation's } \\
\text { food security }\end{array}$ & $\begin{array}{l}\text { 5. The classroom } \\
\text { discussions }\end{array}$ & $\begin{array}{l}\text { 5. The level of respect } \\
\text { shown to me }\end{array}$ & $\begin{array}{l}\text { 5. A "bad" YAPA } \\
\text { experience }\end{array}$ \\
\hline $\begin{array}{l}\text { 6. To make farming my } \\
\text { main means of living }\end{array}$ & $\begin{array}{l}\text { 6. Opportunities to visit } \\
\text { farms/ farmers to learn }\end{array}$ & $\begin{array}{l}\text { 6. Their management } \\
\text { skills }\end{array}$ & $\begin{array}{l}6 . \text { The hard work, low } \\
\text { returns to farming }\end{array}$ \\
\hline $\begin{array}{l}\text { 7. Wanted to get into the } \\
\text { Training at (ECIAF) }\end{array}$ & $\begin{array}{l}\text { 7. Projects, other than } \\
\text { farming involved with }\end{array}$ & $\begin{array}{l}7 \text { In setting a good } \\
\text { example for trainees }\end{array}$ & $\begin{array}{l}\text { 7. Low prestige/status } \\
\text { of agriculture, }\end{array}$ \\
\hline $\begin{array}{l}\text { 8. Heard about a promise } \\
\text { of land by Government }\end{array}$ & $\begin{array}{l}\text { 8. The respect provided } \\
\text { by the trainers to you }\end{array}$ & $\begin{array}{l}\text { 8. In lending their } \\
\text { support when I have } \\
\text { home or other problems } \\
\text { heavy on my mind }\end{array}$ & $\begin{array}{l}\text { 8. Friends/Family } \\
\text { pressure to get out of } \\
\text { agriculture }\end{array}$ \\
\hline $\begin{array}{l}\text { 9. Parents/family are into } \\
\text { farming }\end{array}$ & $\begin{array}{l}\text { 9. Agricultural projects } \\
\text { involved with }\end{array}$ & $\begin{array}{l}\text { 9. Their concern about } \\
\text { the problems I face } \\
\text { outside the classroom }\end{array}$ & \\
\hline $\begin{array}{l}\text { 10. Needed the stipend } \\
\text { being provided }\end{array}$ & $\begin{array}{l}\text { 10. Cooperation of YAPA } \\
\text { trainees }\end{array}$ & $\begin{array}{l}\text { 10. Their sensitivity the } \\
\text { issues young people } \\
\text { face daily }\end{array}$ & \\
\hline $\begin{array}{l}\text { 11. Parents have land, } \\
\text { other resources }\end{array}$ & $\begin{array}{l}\text { 11. The amount of } \\
\text { classroom work done }\end{array}$ & & \\
\hline 12. Influence of parents & $\begin{array}{l}\text { 12. The facilities for } \\
\text { changing, washing, } \\
\text { lavatory, etc } \\
\end{array}$ & & \\
\hline \multicolumn{4}{|l|}{$\begin{array}{l}\text { 13. Studied Agricultural } \\
\text { Science at school }\end{array}$} \\
\hline \multicolumn{4}{|l|}{$\begin{array}{l}\text { 14. Was not employed } \\
\text { when I heard about the } \\
\text { programme }\end{array}$} \\
\hline 15. Influence of friends & & & \\
\hline
\end{tabular}




\section{Perception of the trainers}

The majority of trainees rated trainers' knowledge of agriculture and their practical farming skills as good or very good, attracting highest mean scores. Their "management skills" were rated lower. Trainers' interest in helping trainees, motivational skills and "respect shown" were also rated highly. Trainers' abilities in the student welfare areas of "lending support to them," being concerned "about the problems they faced outside the classroom" and "their sensitivity to young people's issues" were ranked lowest.

\section{Reasons not to pursue farming as a career}

Overall, trainees indicated that getting "some other job offer" would be their top reason for not pursuing a career in farming followed by "insufficient technical support." Mid-ranked reasons to exit the industry were if they "do not get further assistance, e.g. loans," "do not get the land they heard was promised" and "the hard work/low returns to farming." The "low status of farming" and "friends/family pressure to get out of farming" were the least likely reasons to influence their decisions to leave farming.

\section{Attitude of present trainees}

Overall mean scores showed that present trainees' attitude towards agriculture was positive to a large extent (73\%) with $46 \%$ having strong positive attitudes toward farming. A fair amount however $(27 \%)$, assessed farming as being a negative. Table 3 shows details of attitude item responses for present and past YAPA trainees.

\section{Positive predispositions}

Table 3 reflects that the majority of trainees generally agreed that "agriculture plays an important part of the economy" and they wanted to get into agriculture to "make a significant contribution to food security." As young persons, they felt that they could "influence agriculture development" and "change the face of farming in the country." Most also felt that they could "make a successful career in farming."

Their positive attitudes were also reflected in their disagreement to several negative statements presented to them. They disagreed strongly that farming "is only for those who do not do well in school" and "is a dead-end job" or is for "uneducated people." They rejected that "they were sometimes ashamed to let people know they were in farming" and not averse to "encourage friends to be involved in farming."

\section{Negative Predispositions}

Trainees' negative attitudes were determined based on agreement to several negative statements presented to them. Trainees strongly agreed that "unavailability of land, water and credit are some of the major concerns in farming." To a lesser extent, they felt that "government does not appear to have a clear plan to improve agriculture," and to some extent that "they will pursue other options other than farming" if they have a choice.

Negative attitudes were also reflected in trainees' strong disagreement to the positively worded statements "farming is the only career for me" and "the low status of farming doesn't bother me" (see Table 3). 
Table 3

Means, Standard Deviations and percent responses to attitude statements for trainees presently in YAPA and those post YAPA $(\mathrm{N}=37)$

\begin{tabular}{|c|c|c|c|c|c|c|c|}
\hline Attitude Statements & Mean & (SD) & SA & $\mathbf{A}$ & $\mathbf{U}$ & D & SD \\
\hline 1. Farming has no future in this country. & $\begin{array}{l}\text { Pre } \\
\text { Post }\end{array}$ & $\begin{array}{l}3.8(1.3) \\
4.1(.95)\end{array}$ & $\begin{array}{l}10.5 \\
13.5\end{array}$ & $\begin{array}{l}10.5 \\
0\end{array}$ & $\begin{array}{l}7 \\
0\end{array}$ & $\begin{array}{l}29.8 \\
51.4\end{array}$ & $\begin{array}{l}42.2 \\
35.1\end{array}$ \\
\hline 2. Farming is a dead end job. & $\begin{array}{l}\text { Pre } \\
\text { Post }\end{array}$ & $\begin{array}{l}4.3(1.0) \\
4.3(.62)\end{array}$ & $\begin{array}{l}5.3 \\
0\end{array}$ & $\begin{array}{l}1.8 \\
2.7\end{array}$ & $\begin{array}{l}7 \\
0\end{array}$ & $\begin{array}{l}28.1 \\
62.2\end{array}$ & $\begin{array}{l}57.8 \\
35.1\end{array}$ \\
\hline $\begin{array}{l}\text { 3. I will pursue career options other } * \\
\text { than farming if I have a choice. }\end{array}$ & $\begin{array}{l}\text { Pre } \\
\text { Post }\end{array}$ & $\begin{array}{l}2.4(1.2) \\
2.7(.95) \\
\end{array}$ & $\begin{array}{ll}19.3 \\
2.7\end{array}$ & $\begin{array}{l}42.1 \\
37.8\end{array}$ & $\begin{array}{l}17.5 \\
35.1\end{array}$ & $\begin{array}{l}12.3 \\
18.9 \\
\end{array}$ & $\begin{array}{l}8.8 \\
5.5\end{array}$ \\
\hline $\begin{array}{l}\text { 4. More and more I feel helpless in } \\
\text { the face of what is happening in farming today. }\end{array}$ & $\begin{array}{l}\text { Pre } \\
\text { Post }\end{array}$ & $\begin{array}{l}2.9(1.1) \\
2.4(1.3)\end{array}$ & $\begin{array}{l}17.5 \\
21.6\end{array}$ & $\begin{array}{l}36.8 \\
51.4\end{array}$ & $\begin{array}{l}21.1 \\
5.4\end{array}$ & $\begin{array}{l}19.3 \\
10.8\end{array}$ & $\begin{array}{l}5.3 \\
10.8\end{array}$ \\
\hline $\begin{array}{l}\text { 5. I will not encourage my friends to be } \\
\text { involved in farming. }\end{array}$ & $\begin{array}{l}\text { Pre } \\
\text { Post }\end{array}$ & $\begin{array}{l}4.1(.99) \\
4.1(1.0)\end{array}$ & $\begin{array}{l}3.5 \\
8.1\end{array}$ & $\begin{array}{l}5.3 \\
0\end{array}$ & $\begin{array}{l}7.0 \\
0\end{array}$ & $\begin{array}{l}47.4 \\
62.2\end{array}$ & $\begin{array}{l}36.8 \\
29.7\end{array}$ \\
\hline $\begin{array}{l}\text { 6. As a young person, I can influence } \\
\text { agricultural development. }\end{array}$ & $\begin{array}{l}\text { Pre } \\
\text { Post }\end{array}$ & $\begin{array}{l}4.2(.79) \\
4.2(.62)\end{array}$ & $\begin{array}{l}43.8 \\
32.4\end{array}$ & $\begin{array}{l}45.6 \\
62.2\end{array}$ & $\begin{array}{l}3.5 \\
5.4\end{array}$ & $\begin{array}{l}5.3 \\
0\end{array}$ & $\begin{array}{l}1.8 \\
0\end{array}$ \\
\hline $\begin{array}{l}\text { 7. I believe I can make a significant } \\
\text { contribution to the food security of this country. }\end{array}$ & $\begin{array}{l}\text { Pre } \\
\text { Post }\end{array}$ & $\begin{array}{l}4.3(.79) \\
4.2(.62) \\
\end{array}$ & $\begin{array}{l}42.1 \\
27.0\end{array}$ & $\begin{array}{l}47.3 \\
67.6 \\
\end{array}$ & $\begin{array}{l}5.3 \\
2.7\end{array}$ & $\begin{array}{l}5.3 \\
2.7\end{array}$ & $\begin{array}{l}0 \\
0 \\
\end{array}$ \\
\hline $\begin{array}{l}\text { 8. I am sometimes ashamed to let people * } \\
\text { know I/am involved in farming }\end{array}$ & $\begin{array}{l}\text { Pre } \\
\text { Post }\end{array}$ & $\begin{array}{l}4.1(.96) \\
4.5(.51) \\
\end{array}$ & $\begin{array}{l}5.3 \\
0\end{array}$ & $\begin{array}{ll}1.8 \\
0\end{array}$ & $\begin{array}{l}3.5 \\
0\end{array}$ & $\begin{array}{l}54.3 \\
48.6\end{array}$ & $\begin{array}{l}35.1 \\
51.4\end{array}$ \\
\hline $\begin{array}{l}\text { 9. I like farming because it is a natural * } \\
\text { way of life. }\end{array}$ & $\begin{array}{l}\text { Pre } \\
\text { Post }\end{array}$ & $\begin{array}{l}3.7(1.0) \\
4.2(.64)\end{array}$ & $\begin{array}{l}19.3 \\
32.4\end{array}$ & $\begin{array}{l}57.8 \\
62.2\end{array}$ & $\begin{array}{l}8.8 \\
2.7\end{array}$ & $\begin{array}{l}8.8 \\
2.7\end{array}$ & $\begin{array}{l}5.3 \\
0\end{array}$ \\
\hline $\begin{array}{l}\text { 10. The best future for farming lies in the } \\
\text { continued use of new technology. }\end{array}$ & $\begin{array}{l}\text { Pre } \\
\text { Post }\end{array}$ & $\begin{array}{l}4.0(.98) \\
3.9(.89) \\
\end{array}$ & $\begin{array}{l}36.8 \\
18.9 \\
\end{array}$ & $\begin{array}{l}40.4 \\
67.6 \\
\end{array}$ & $\begin{array}{ll}14.0 \\
2.7\end{array}$ & $\begin{array}{l}7.0 \\
8.1\end{array}$ & $\begin{array}{l}1.8 \\
2.7\end{array}$ \\
\hline 11 Farming is the only career for me. * & $\begin{array}{l}\text { Pre } \\
\text { Post }\end{array}$ & $\begin{array}{l}2.3(1.1) \\
2.8(1.1)\end{array}$ & $\begin{array}{l}7.0 \\
10.8\end{array}$ & $\begin{array}{l}5.3 \\
10.8\end{array}$ & $\begin{array}{l}21.1 \\
35.2\end{array}$ & $\begin{array}{l}38.5 \\
35.1\end{array}$ & $\begin{array}{l}28.1 \\
8.1\end{array}$ \\
\hline $\begin{array}{l}\text { 12. The future of farming is bright } * \\
\text { in this country }\end{array}$ & $\begin{array}{l}\text { Pre } \\
\text { Post }\end{array}$ & $\begin{array}{l}3.3(1.2) \\
2.9(1.2) \\
\end{array}$ & $\begin{array}{l}15.8 \\
8.2\end{array}$ & $\begin{array}{l}36.8 \\
29.7\end{array}$ & $\begin{array}{l}19.3 \\
13.5\end{array}$ & $\begin{array}{l}19.3 \\
37.8\end{array}$ & $\begin{array}{l}8.7 \\
10.8\end{array}$ \\
\hline $\begin{array}{l}\text { 13. As currently practiced, farming } \\
\text { is too much hard work }\end{array}$ & $\begin{array}{l}\text { Pre } \\
\text { Post }\end{array}$ & $\begin{array}{l}3.2(1.4) \\
3.3(1.2)\end{array}$ & $\begin{array}{l}12.3 \\
5.4\end{array}$ & $\begin{array}{l}31.6 \\
32.4\end{array}$ & $\begin{array}{l}1.8 \\
5.4\end{array}$ & $\begin{array}{l}31.6 \\
43.2\end{array}$ & $\begin{array}{l}22.7 \\
13.6\end{array}$ \\
\hline $\begin{array}{l}\text { 14. I will be more interested in farming if equipment } \\
\text { is made available to reduce the hard work * }\end{array}$ & $\begin{array}{l}\text { Pre } \\
\text { Post }\end{array}$ & $\begin{array}{l}4.0(1.8) \\
2.2(.99)\end{array}$ & $\begin{array}{l}43.9 \\
5.4\end{array}$ & $\begin{array}{l}35.1 \\
5.4\end{array}$ & $\begin{array}{l}3.5 \\
8.1\end{array}$ & $\begin{array}{l}14.0 \\
62.2\end{array}$ & $\begin{array}{l}3.5 \\
18.9\end{array}$ \\
\hline $\begin{array}{l}\text { 15. Unavailability of land and water * } \\
\text { and the absence of credit are some of the major } \\
\text { concerns in farming. }\end{array}$ & $\begin{array}{l}\text { Pre } \\
\text { Post }\end{array}$ & $\begin{array}{l}1.5(.97) \\
1.8(.74)\end{array}$ & $\begin{array}{l}68.4 \\
29.7\end{array}$ & $\begin{array}{l}22.8 \\
64.9\end{array}$ & $\begin{array}{l}1.8 \\
2.7\end{array}$ & $\begin{array}{l}3.5 \\
0\end{array}$ & $\begin{array}{l}3.5 \\
2.7\end{array}$ \\
\hline $\begin{array}{l}\text { 16. There are just too many problems } \\
\text { in agriculture today }\end{array}$ & $\begin{array}{l}\text { Pre } \\
\text { Post }\end{array}$ & $\begin{array}{l}2.7(1.2) \\
2.6(1.2) \\
\end{array}$ & $\begin{array}{l}12.3 \\
13.5 \\
\end{array}$ & $\begin{array}{l}43.8 \\
45.9\end{array}$ & $\begin{array}{l}12.3 \\
10.8\end{array}$ & $\begin{array}{l}22.8 \\
24.3\end{array}$ & $\begin{array}{l}8.8 \\
5.5\end{array}$ \\
\hline $\begin{array}{l}\text { 17. The incentives to farming * } \\
\text { are not encouraging }\end{array}$ & $\begin{array}{l}\text { Pre } \\
\text { Post }\end{array}$ & $\begin{array}{l}3.2(1.3) \\
2.7(1.1) \\
\end{array}$ & $\begin{array}{l}10.5 \\
13.5\end{array}$ & $\begin{array}{l}22.8 \\
37.8\end{array}$ & $\begin{array}{l}14.0 \\
24.3 \\
\end{array}$ & $\begin{array}{l}38.6 \\
18.9 \\
\end{array}$ & $\begin{array}{l}14.1 \\
5.5\end{array}$ \\
\hline $\begin{array}{l}\text { 18. People do not recognize } \\
\text { the importance of agriculture }\end{array}$ & $\begin{array}{l}\text { Pre } \\
\text { Post }\end{array}$ & $\begin{array}{l}4.3(.88) \\
4.5(.56) \\
\end{array}$ & $\begin{array}{l}45.6 \\
48.6\end{array}$ & $\begin{array}{l}43.8 \\
48.6\end{array}$ & $\begin{array}{l}1.8 \\
2.8\end{array}$ & $\begin{array}{l}8.8 \\
0\end{array}$ & $\begin{array}{l}0 \\
0\end{array}$ \\
\hline $\begin{array}{l}\text { 19. I can make a successful career } \\
\text { in farming given the chance. }\end{array}$ & $\begin{array}{l}\text { Pre } \\
\text { Post }\end{array}$ & $\begin{array}{l}4.2(.88) \\
4.4(.66)\end{array}$ & $\begin{array}{l}42.1 \\
48.6\end{array}$ & $\begin{array}{l}43.9 \\
45.9\end{array}$ & $\begin{array}{l}8.8 \\
5.5\end{array}$ & $\begin{array}{l}3.5 \\
0\end{array}$ & $\begin{array}{l}1.7 \\
0\end{array}$ \\
\hline $\begin{array}{l}\text { 20. Agriculture plays an } \\
\text { important part in the economy. }\end{array}$ & \begin{tabular}{|l} 
Pre \\
Post
\end{tabular} & $\begin{array}{l}4.5(.95) \\
4.5(.56)\end{array}$ & $\begin{array}{l}73.7 \\
54.1\end{array}$ & $\begin{array}{l}17.5 \\
43.2\end{array}$ & $\begin{array}{l}0 \\
2.7\end{array}$ & $\begin{array}{l}7.0 \\
0\end{array}$ & $\begin{array}{l}1.8 \\
0\end{array}$ \\
\hline $\begin{array}{l}\text { 21. It does not appear that Government has a clear } \\
\text { plan to improve agriculture. }\end{array}$ & $\begin{array}{l}\text { Pre } \\
\text { Post }\end{array}$ & $\begin{array}{l}2.3(1.4) \\
2.0(1.0)\end{array}$ & $\begin{array}{l}36.8 \\
35.1\end{array}$ & $\begin{array}{l}31.6 \\
40.5\end{array}$ & $\begin{array}{l}1.8 \\
16.2\end{array}$ & $\begin{array}{l}19.3 \\
5.5\end{array}$ & $\begin{array}{l}10.5 \\
2.7\end{array}$ \\
\hline $\begin{array}{l}\text { 22. The low status of farming * } \\
\text { does not bother me. }\end{array}$ & $\begin{array}{l}\text { Pre } \\
\text { Post }\end{array}$ & $\begin{array}{l}2.5(1.3) \\
3.1(1.3) \\
\end{array}$ & $\begin{array}{l}8.8 \\
5.4\end{array}$ & $\begin{array}{l}24.6 \\
51.4\end{array}$ & $\begin{array}{l}0 \\
8.1 \\
\end{array}$ & $\begin{array}{l}38.5 \\
13.5\end{array}$ & $\begin{array}{l}28.1 \\
21.6\end{array}$ \\
\hline $\begin{array}{l}\text { 23. Youths like me have too little } \\
\text { say in what should be done to improve farming. }\end{array}$ & $\begin{array}{l}\text { Pre } \\
\text { Post }\end{array}$ & $\begin{array}{l}1.8(.93) \\
1.9(1.1) \\
\end{array}$ & $\begin{array}{l}45.6 \\
35.1\end{array}$ & $\begin{array}{l}43.9 \\
51.4\end{array}$ & $\begin{array}{l}1.8 \\
2.7\end{array}$ & $\begin{array}{l}7.0 \\
2.7\end{array}$ & $\begin{array}{l}1.7 \\
8.1\end{array}$ \\
\hline $\begin{array}{l}\text { 24. Farming is only for those who } \\
\text { do not do well in school. }\end{array}$ & $\begin{array}{l}\text { Pre } \\
\text { Post }\end{array}$ & $\begin{array}{l}4.6(.75) \\
4.3(.69)\end{array}$ & $\begin{array}{l}0 \\
2.7 \\
\end{array}$ & $\begin{array}{l}3.5 \\
2.7\end{array}$ & $\begin{array}{l}5.3 \\
2.7 \\
\end{array}$ & $\begin{array}{l}22.8 \\
37.8\end{array}$ & $\begin{array}{l}68.4 \\
54.1\end{array}$ \\
\hline $\begin{array}{l}\text { 25. Youth can change the face } \\
\text { of farming in this country. }\end{array}$ & $\begin{array}{l}\text { Pre } \\
\text { Post }\end{array}$ & $\begin{array}{l}4.1(.88) \\
4.4(.55)\end{array}$ & $\begin{array}{l}40.4 \\
45.9\end{array}$ & $\begin{array}{l}38.6 \\
51.4\end{array}$ & $\begin{array}{l}15.7 \\
2.7\end{array}$ & $\begin{array}{l}5.3 \\
0\end{array}$ & $\begin{array}{l}0 \\
0\end{array}$ \\
\hline $\begin{array}{l}\text { 26. Farming is a profession for * } \\
\text { uneducated people only. }\end{array}$ & \begin{tabular}{|l} 
Pre \\
Post
\end{tabular} & $\begin{array}{l}4.2(1.0) \\
4.6(.49) \\
\end{array}$ & $\begin{array}{l}3.5 \\
0\end{array}$ & $\begin{array}{l}3.5 \\
0\end{array}$ & $\begin{array}{l}12.3 \\
0\end{array}$ & $\begin{array}{l}31.6 \\
37.8\end{array}$ & $\begin{array}{l}49.1 \\
62.2 \\
\end{array}$ \\
\hline
\end{tabular}

*Significantly different $(\mathrm{P}<.05)$ based on Mann-Whitney $\mathrm{U}$ 


\section{Changed attitudes of past YAPA trainees}

Several significant differences were noted by the responses to several item statements between present trainees and past trainees. While both groups would "pursue other career options other than farming," past trainees were less inclined to than present trainees, were less ashamed "to let people know that they were involved in farming' than present trainees, and were significantly stronger in their appreciation of "farming as a way of life" than present trainees. While both groups didn't hold strongly that farming would be their only career, present trainees were significantly stronger in this belief than past trainees. Past trainees however, were significantly less optimistic than present trainees as reflected in their response to the statement that the "future of farming is bright." On the statements that dealt with availability of availability of equipment, provision of incentives and adequate access to resources, past trainees were less enthusiastic about these than present trainees. On the two statements that dealt with the perceived low status of farming being an obstacle and the low regard others hold about the agricultural profession, past YAPA trainees were less inclined to be turned off by these negativities.

\section{Discussion}

\section{Reasons for entering the program}

The consistent priority reason trainees chose to enter the YAPA programme shows that they consider agriculture as an extra activity to generate additional income. Making a career out of farming is ranked lower. Trainees, wanting to use the YAPA as a stepping-stone for further formal education in Agriculture, while important, was not a foremost reason. The receipt of land to do farming appeared not to be the overriding determinant of their decision to enter the programme.

The stated policy of creating a new cadre of farmers has to be redefined to explicitly state that it is full-time farming that is desired. The criteria for YAPA participation must be clearly stated and understood by participants prior to entry. The idea of part time farming, for additional income needs to be re-evaluated. Firstly, the curriculum should be reconstructed to place greater emphasis on attitude adjustment and entrepreneurship. However, and perhaps of greater importance, the Ministry should take decisive actions that demonstrate that they seriously want to invest in youth. Actions such as the provision of access to resources to develop meaningful economic size units must be taken. Without such support trainees can only hope to pursue the business of agriculture on a part-time basis.

\section{Perception of program elements}

The obvious strengths of the training component are the field exercises, the equipment provided to do the field aspects and the quality of the discussions that take place in the field about farming. Programme directors need to take a look at the knowledge and skills of the trainers. While most may have excellent knowledge and skills, those that are deficient need to be either upgraded or redirected elsewhere. The need for all training staff to respect trainees must be emphasized. Proper orientation for staff chosen to be involved in the YAPA and probably a code of conduct may help in this regard. Orientation for trainees, coupled with sessions that deal with group interaction, cooperation etc., interspersed throughout the programme, will also help to improve the level of co-operation among trainees.

Where the physical facilities for storage, changing, washing etc., are inadequate, they must be improved immediately. A programme that has an average $50 \%$ female involvement should not 
be conducted in the absence of adequate and gender appropriate sanitary facilities at training or farming sites in general.

Trainees call for "more classroom work," suggests a cry for greater understanding of principles and concepts. Rather than inflict these trainees with long sessions in classrooms, coordinators and trainers need to involve them in participatory learning activities. In this regard, staff may need training to conduct these types of "action and reflection" techniques. A shift of emphasis is needed to place as much emphasis on why things are done, as is presently placed on how to do things. Many trainees come without having any experience in farming or any formal training in agriculture. Knowledge development as a necessary precondition for skills development must be trainers' goal. We should seek to develop a cadre of "intelligent farmers" rather than skilled labourers, and promote an atmosphere in which innovation is encouraged. Technology use must be the focus of training to reduce the drudgery and stigmas associated with present day farming in the region.

\section{Perception of trainers}

Trainees generally have confidence in the technical knowledge and skills of the trainers. They also indicated that trainers were good motivators and were genuinely interested in helping them become true farmers. Trainees rated trainers' managerial skills, level of respect shown and setting a good example modestly. Trainers' ability to deal with non-agricultural and personal problems of trainees was perceived as inadequate. Several opportunities exist to improve the level of respect shown by trainers to trainees and the need to set good examples. This can be accomplished by a proper orientation for the facilitators and other persons involved in training and interacting closely with trainees before the start of the programme. It should include the setting of norms and expectations and a code of conduct.

YAPA trainers cannot be expected to adequately treat trainees' personal problems without proper training. The programme must engage trained counselors at the start of the programme and periodically to assist trainees in this regard.

\section{Reasons for not pursuing agriculture}

The overall results tend to suggest that the trainees did not see farming/agriculture as a longterm career. If they got another job, they would leave farming. Most likely they would farm on a part-time, limited scale on available land. This strong reason for leaving agriculture would be strengthened even further if they do not get technical support from the Ministry of Agriculture, loans to pursue farming and of course, land on which to farm.

These are the overriding reasons and suggest that these are key ingredients for young persons continued involvement in farming. These factors should be in place immediately upon graduation of successful trainees from the YAPA 2 programme. Any time lapse is a huge window for them to seek out other job opportunities. Land for farming is critical in the Caribbean region where most countries have small land masses with many competing interests for available land. However, creative measures can be implemented such as intensive, technology driven agriculture and group or cooperative farming methods.

\section{Attitudes}

While overall, most trainees had positive attitudes to farming, fair amounts had negative attitudes. Their positive attitudes are reflected in their contextual view of agriculture, their zeal to contribute, influence agricultural development and generate some income from farming. They rejected the suggestions that agriculture is only a dead-end job, is not a career to be 
pursued, is only for those who fail in academic subjects, and is not a profession of which one can be proud.

Those trainees with negative views were disenchanted with the perceived lack of a clear plan by government for youth's role in the development of the sector, the perceived unavailability of resources to assist them and their lack of voice on the matter. They expressed some helplessness in the situation and indicated that farming will not be the only career for them.

If these respondents represent the pool from which young farmers will come, then action should be taken to improve their present dispositions. Young people should be more involved in development plans for the sector. It is insufficient for government to plan a youth program without the active, full engagement of young persons in its design. Further, agriculture needs to be presented to them as a professional career, not an activity to be pursued in addition to some other 'main' career. It must be shown to be economically viable and competitive with their alternative use of resources or career options. Incorporating an agribusiness component as a main part of the programme and actions to provide them with adequate resources to start farming as soon as they complete the program successfully will be steps in the right direction.

\section{Changed attitudes}

Past YAPA trainees did not appear to be negatively affected by of the fact that they were not being actively supported to pursue their careers in agriculture. Probably, the six month time frame for assessment was too short, but it seems that urgent positive action by Government and other agencies could capitalize on this goodwill and that failure to act would have serious implications for further youth engagement in the sector. Government simply cannot afford to take such a risk at this time given the situation of the aging farmer population in the region. Furthermore, this has implications for the entire region, as other countries face a similar challenge and are looking for a youth engagement model to follow.

\section{Conclusion}

The YAPA programme was designed to meet a significant need in the area of agriculture skill development as a stepping stone towards youth engagement of the farming sector in Trinidad. However, findings from this study suggest that significant changes need to happen in order for YAPA to truly meet its mission. While trainees (we only reported trainees' opinions in this study) expressed some concerns with the overall programme, they were also mindful in noting the positive aspects. It can be determined from participants' comments that the YAPA has met a number of their expectations and has played a role in the development of the agriculture sector and youth development. Notwithstanding, the negativities revealed by study, participants expressed the need for restructuring and redirection of the entire programme.

The Government must be responsive to the needs of all YAPA participants and use their feedback in order to institute changes. Addressing these changes will definitely enhance the intended structure and help participants leave with a more meaningful experience.

Furthermore, by addressing the aforementioned issues, the Trinidad government sets itself up to be a leader in the development of a model that meets the looming agricultural issues within the Caribbean region, since the problem of inadequate youth engagement in agriculture is regional. 


\section{References}

Divyakirti, V. (2002). Rural Development: The Strategic Option of Youth Employment. Paper presented at the Youth Employment Summit, Alexandria, Egypt. Retrieved March 15, 2007, from http://www.fabi.it/giovani/congresso/DOCUMENTI/rural dev.pdf

Food and Agricultural Organization (FAO) of the United Nations. (2001). Report on Enhancement of farm youth Network for Agricultural career. Department of Agricultural Extension, FAO.

James, O. (2005). Journal of Agriculture And Social Research, 5(1), 48-53.

Ministry of Agriculture, Land, \& Marine Resources, The. (2004). Programmes and Projects Agricultural Incentive. Retrieved February 26, 2007, from The Government of the Republic of Trinidad and Tobago website:

http://www.agriculture.gov.tt/applicationloader.asp?app=articles\&id=1061

Odhiambo, E.O. (2001). The role of rural youth in promoting conservation agriculture in Kenya, Kenya Youth Foundation.

Rivera, William M. (2001). Agricultural and Rural Extension Worldwide: Options for Institutional Reform in the Developing Countries, FAO, Rome.

Russell, E. (1993). Attracting Youth to Agriculture. Journal of Extension, 31(4). Retrieved March 15, 2007, from http://www.joe.org/joe/1993winter/a2.html

World Bank, The. (2001). World Development Indicators: 2001. New York, NY: Oxford University Press.

World Bank, The. (2006a). Rural Development \& Agriculture in Papua New Guinea. Retrieved March 15, 2007, from http://go.worldbank.org/S4LJLNM0CO

World Bank, The. (2006b). Urgent Need to Invest More in Developing World's Record Youth population, Says World Development Report. Retrieved March 15, 2007, from http://go.worldbank.org/L889ZRIN20

(C) Copyright of Journal of Youth Development Bridging Research and Practice. Content may not be copied or emailed to multiple sites or posted to a listserv without copyright holder's express written permission. However, users may print, download or email articles for individual use. 